Article

\title{
Chromosome Conformation Capture Reveals Two Elements That Interact with the PTBP3 (ROD1) Transcription Start Site
}

\author{
Marta Kubiak ${ }^{1,2}$, Anna Jurek ${ }^{1}$, Katarzyna Kamińska ${ }^{1}$, Janusz Kowalewski ${ }^{2}$, Sui Huang ${ }^{3}$ and $^{1}$ \\ Marzena Anna Lewandowska 1,2,* \\ 1 Innovative Medical Forum, The F. Lukaszczyk Oncology Center, Department of Molecular Oncology and \\ Genetics, 85-796 Bydgoszcz, Poland; kubiak.marta@co.bydgoszcz.pl (M.K.); ania.m.jurek@gmail.com (A.J.); \\ kaminskak@co.bydgoszcz.pl (K.K.) \\ 2 The Ludwik Rydygier Collegium Medicum, Department of Thoracic Surgery and Tumours, \\ Nicolaus Copernicus University, 85-796 Bydgoszcz, Poland; kowalewskij@co.bydgoszcz.pl \\ 3 Department of Cell and Molecular Biology, Northwestern University Feinberg School of Medicine, \\ Chicago, IL 60611, USA; s-huang2@northwestern.edu \\ * Correspondence: lewandowskam@co.bydgoszcz.pl; Tel.: +48-52-374-3030
}

Received: 1 November 2018; Accepted: 3 January 2019; Published: 9 January 2019

\begin{abstract}
The long-range control of gene expression is facilitated by chromatin looping and can be detected using chromosome conformation capture-3C. Here we focus on the chromatin architecture of the PTBP3 (Polypyrimidine tract binding protein 3) locus to evaluate its potential role in regulating expression of the gene. РТВP3 expression in prostate cancer cell lines is found significantly higher compared to skin fibroblasts using real-time PCR $(p<0.05)$ and digital droplet PCR $(p<0.01)$. Exploration of the chromatin spatial architecture of a nearly 200-kb fragment of chromosome 9 encompassing the $P T B P 3$ gene identified two elements located $63 \mathrm{~kb}$ upstream and $48 \mathrm{~kb}$ downstream of $P T B P 3$, which looped specifically to the $Р T B P 3$ promoter. These elements contain histone acetylation patterns characteristic of open chromatin regions with active enhancers. Our results reveal for the first time that long-range chromatin interactions between the $-63 \mathrm{~kb}$ and $+48 \mathrm{~kb}$ loci and the PTBP3 promoter regulate the expression of this gene in prostate cancer cells. These interactions support an open chromatin form for the PTBP3 locus in cancer cells and the three-dimensional structural model proposed in this paper.
\end{abstract}

Keywords: chromatin conformation; PTBP3; ROD1 (Regulator Of Differentiation 1); cancer epigenetic; gene expression regulation; prostate cancer

\section{Introduction}

Regulation of gene expression involves multiple mechanisms at various stages leading to decreased or increased protein synthesis. Gene regulation at the transcription level is a combination of effects of chromatin conformation and interaction between the complex transcription machinery and DNA [1]. Post-transcriptional modifications control gene expression at the mRNA stage [2], and translational regulation affects the level of protein synthesized from mRNA by, for instance, controlling ribosome recruitment [3]. Epigenetic mechanisms involve DNA modification or post-translational modification of proteins that are closely associated with DNA as key mediators [4].

Some of the best known gene regulation mechanisms which play an important role in cancer development are: DNA methylation, gene silencing by microRNA or histone modifications [5]. In the recent years, chromatin was elevated to a key position as a mediator of the transformation of a normal cell into a malignant state [6]. Modifications such as acetylation of histones (H3K27ac, H3K9ac) and 
their methylation (H3K4, H3K36) may activate spatial organization of chromatin structure to produce a transcriptionally activated state [7]. Regulatory elements may interact with target genes or other regulatory elements over large genomic distances or can even activate the expression of genes located on different chromosomes [8]. Over the last 15 years, the development of Chromosome Conformation Capture (3C) and its subsequent high-throughput variants (4C [9,10], 5C [11], HiC [12], T2C [13], Capture C [14]) has given insights to better understand chromatin 3D organization and its correlation with the regulation mechanisms of gene expression [15].

PTBP1 (Polypyrimidine tract binding protein $1,1 \mathrm{hnRNP}$ I) is a gene encoding a multifunctional protein mainly known for its role in tissue-specific regulation of exon splicing [16-18]. PTBP1 is a member of a larger family of 4 genes in mammals: PTBP1, PTBP2, PTBP3 and $s m P T B$, characterized by a similar protein architecture and containing four RNA-recognition motifs (RRMs) [19]. We were interested in a PTBP1 paralog, the PTBP3(ROD1) gene (Polypyrimidine tract binding protein 3, NM_005156), which plays a role in the negative regulation of differentiation [20]. ROD1 is expressed preferentially in hematopoietic cells and has a known role in nonsense-mediated mRNA decay (NMD) [21]. Cross-regulation between PTBP1 and РTBP3 by non-productive alternative splicing has been reported [22], but other regulation mechanisms remain to be clarified. The PTBP3 regulation mechanisms have not been thoroughly characterized.

Chromatin loops promote activation of gene expression at the mRNA level. Activation of gene transcription by three-dimensional chromatin architecture has been demonstrated in several genes, e.g., CFTR (Cystic fibrosis transmembrane conductance regulator) [23-25], TNFAIP3 (NF Alpha Induced Protein 3) [26], PPAR $\gamma 2$ Peroxisome Proliferator Activated Receptor Gamma 2) [27]. We observed a significant change in the PTBP3 mRNA levels in cancer cell lines versus normal cells, consistent with high expression in lung cancer [28] and stomach cancer [29]. Therefore, we attempted to use the 3C technique to investigate whether the chromatin architecture of the PTBP3 gene regulates its expression at the transcriptional level in cancer cells.

\section{Results}

\subsection{Levels of PTBP3 $m R N A$ in Prostate Cancer Cell Lines}

To determine whether the mRNA levels of PTBP3 differed between cancerous and non-cancerous cells, two quantitative PCR methods were used: Quantitative reverse transcriptase real-time PCR (qRT-PCR) and digital droplet PCR (ddPCR). The qRT-PCR assay using the Universal ProbeLibrary (UPL) probes involved mRNA level analysis normalized using glyceraldehyde-3-phosphate dehydrogenase (GAPDH) and porphobilinogen deaminase (PBGD). The results were consistent for both housekeeping genes (Figure 1). PTBP3 was increased in prostate cancer cell lines compared to skin fibroblasts with GAPDH as the reference gene. The most significant increase in the PTBP3 mRNA level was observed in the prostate cancer cell lines: PC3M cells $(+/-4.5$-fold, $p<0.001)$ and the PC3 cells $(+/-2$-fold, $p<0.01)$ compared to skin fibroblasts. With $P B G D$ as the reference gene, the most significantly increased level of PTBP3 mRNA was again observed in the PC3M cells (+/ - 3-fold, $p<0.001)$ and the PC3 cells $(+/-2$-fold, $p<0.05)$ vs. skin fibroblasts (Figure 1$)$. As in the qPCR assay, in digital droplet PCR (ddPCR) the most significant increase in the PTBP3 expression was observed in the PC3M cells $(+/-2.5$-fold, $p<0.001)$ and the PC3 cells $(+/-1.4$-fold, $p<0.01)$ compared to skin fibroblasts (Figure 1). 


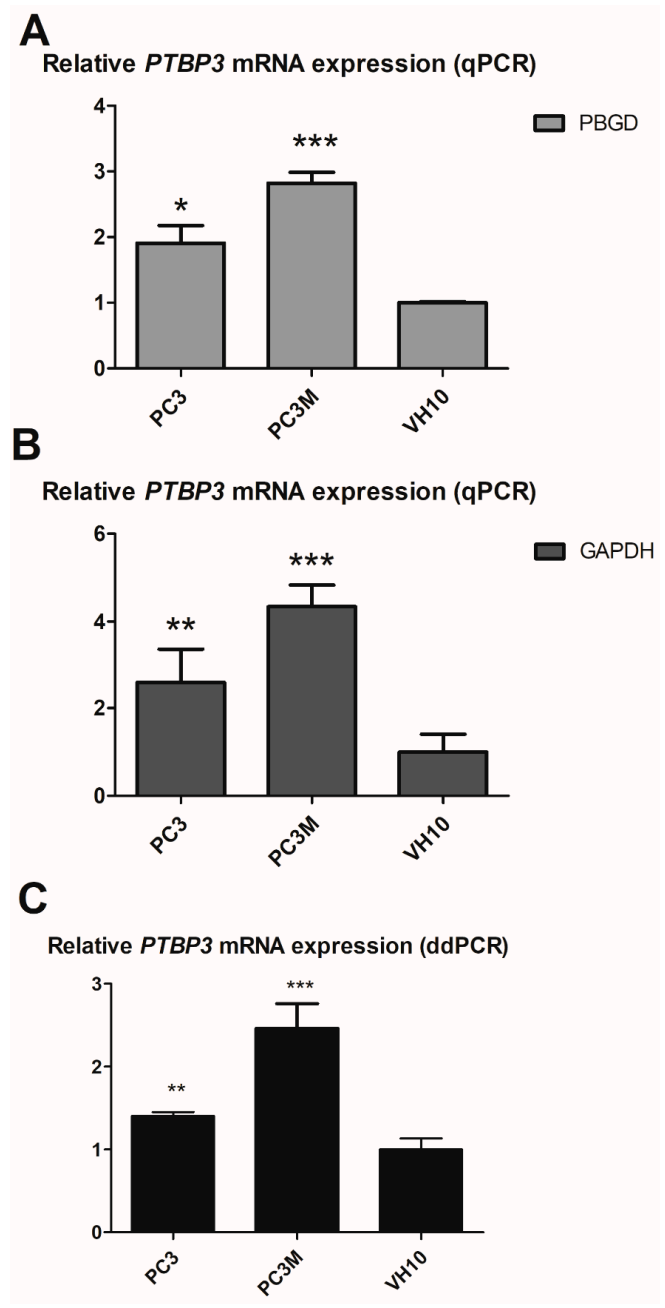

Figure 1. Comparison of the expression of $P T B P 3$ in prostate cancer cell lines. Asterisks represent statistically significant changes in the PTBP3 mRNA levels in prostate cancer cells versus human fibroblasts ${ }^{*} p<0.5 ;{ }^{* *} p<0.01 ;{ }^{* *} p<0.001$. Relative levels of PTBP3 mRNA using quantitative PCR (qPCR) assay. Gray columns represent experiment performed in triplicates with references genes: (A) PBGD and (B) GAPDH; (C) PTBP3 mRNA level using ddPCR assay. Stars represent statistically significant changes in the $P T B P 3$ mRNA levels versus human fibroblasts. Black columns represent experiments performed at least in triplicates.

\subsection{Looping Organization of the PTBP3 Locus in Prostate Cancer Cell Lines}

To investigate the mechanism of higher level of PTBP3 in cancer cells, we examined chromatin interaction of the $P T B P 3$ locus. We used chromosome conformation capture (3C) for the evaluation of long-range chromatin interaction across distant regulatory elements and active $P T B P 3$ promoter. We performed a $3 \mathrm{C}$ experiment using prostate cancer cell lines (PC3 and PC3M) with a statistically significant high expression of $P T B P 3$ versus human skin fibroblasts to identify chromatin interaction across the PTBP3 locus.

To analyze three-dimensional chromatin organization of the $P T B P 3$, we used a $5^{\prime}-3^{\prime}$ ROD1 Reverseprimer, located in the $5^{\prime}$ region upstream of the promoter of $P T B P 3$, and a set of forward primers across a 200-kb region encompassing the PTBP3 locus and flanking regions (Figure 2, Supplementary Table S1). Within the primary human skin fibroblasts, which have a low level of expression of the PTBP3 gene, interaction frequency with the PTBP3 promoter decreased as a function of distance from the promoter, with no significant interaction between the promoter and either of the distal fragments located across the PTBP3 gene. 

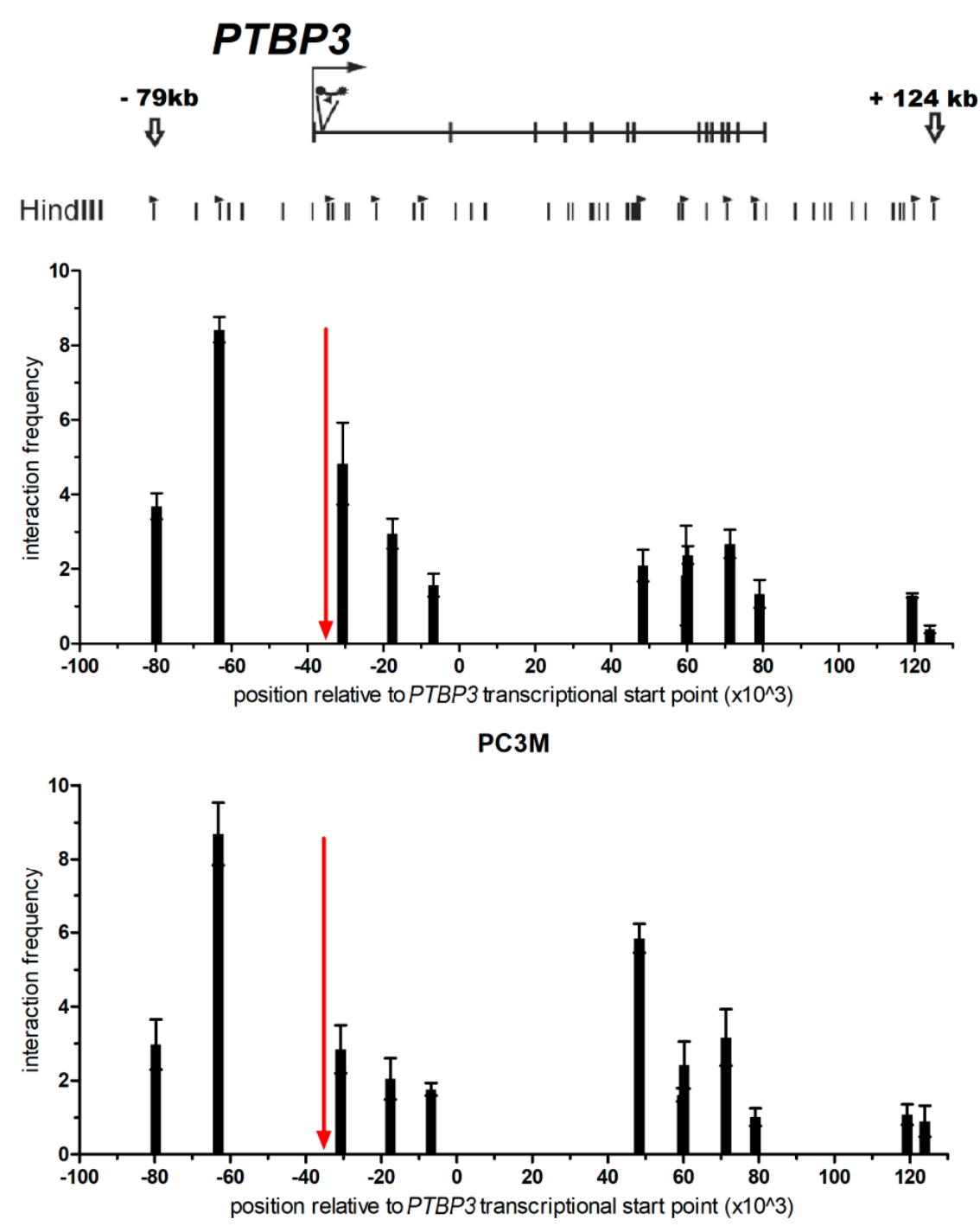

VH10

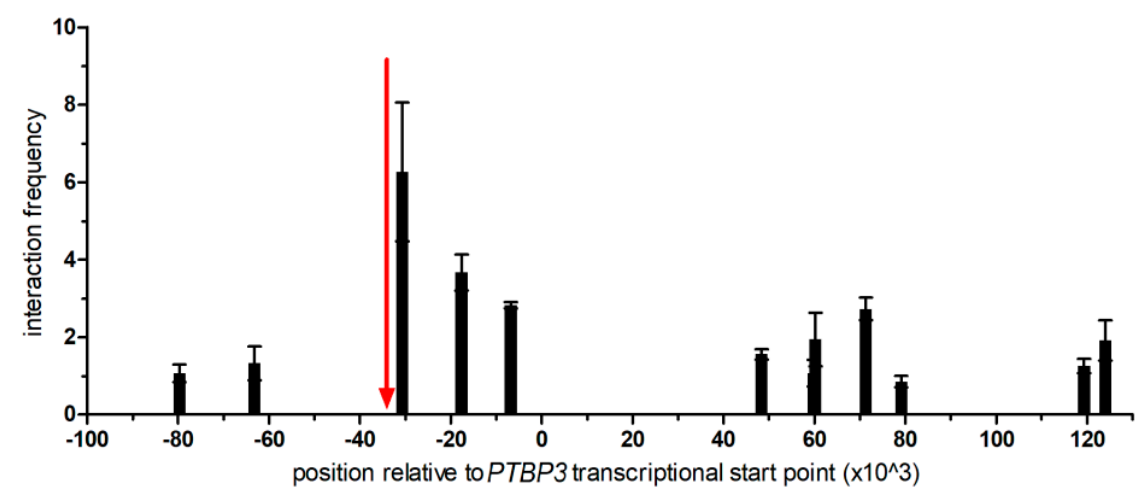

Figure 2. Two elements interacting with the PTBP3 transcription start site (TSS) revealed by chromosome conformation capture (3C). Schematic representation of the PTBP3 gene with exons marked with vertical bars and the TSS represented by a bent arrow. Small vertical lines under the gene indicate HindIII restriction sites, and arrow heads indicate the localization of $3 \mathrm{C}$ primers (black arrows-forward; white arrow-reverse). The black circle with a star represent Taqman probe (bait). The $\mathrm{X}$ axis represents the position relative to the TSS. The $\mathrm{Y}$ axis represents the interaction frequency relative to the interaction frequency between two HindIII fragments within the ubiquitously expressed ERCC3 (ERCC Excision Repair 3) gene. The red arrow represents the bait region of the PTBP3 promoter, which includes a primer and a Taqman probe. The $3 \mathrm{C}$ experiment was performed in triplicates for each $3 \mathrm{C}$ library. 
In prostate cancer cell lines PC3 and PC3M, which express high levels of PTBP3 transcripts, $3 \mathrm{C}$ analysis demonstrated chromatin interaction between the PTBP3 promoter and distal or proximal fragments encompassing regulatory elements.

The highest chromatin interactions within the PTBP3 promoter and distal regions of the gene were observed in the PC3M cell lines with the highest PTBP3 expression. Frequent chromatin interactions were observed for two restriction fragments upstream and downstream of the PTBP3 promoter. One region, encompassing $63 \mathrm{~kb}$ upstream of the TSS, was a fragment also observed in the PC 3 cells with a 3 -fold higher interaction than that observed in a restriction fragment located close to the promoter, and 9-fold higher than the background of non-specific interactions. Another fragment with a high chromatin interaction was identified at the $48 \mathrm{~kb}$ region downstream of the transcription start point. This interaction was 3-fold higher than that observed in a fragment located close to the PTBP3 promoter and 6-fold higher than the background (Figure 2). The interacting fragments located $63 \mathrm{~kb}$ upstream and $48 \mathrm{~kb}$ downstream from the promoter region demonstrated a greater interaction frequency with the PTBP3 promoter than a HindIII fragment located close $(<4 \mathrm{~kb})$ to the PTBP3 promoter (Figure 2).

In the PC3 cells with a significant overexpression of $P T B P 3$, frequent chromatin interactions were observed between the promoter fragment and its nearby restriction fragments. Additionally, frequent interactions with another restriction fragment were found, as evidenced by a local peak in interaction frequency. The interacting fragment was located in the flanking region of the $5^{\prime}$ end of PTBP3 encompassing $63 \mathrm{~kb}$ upstream of the TSS. The chromatin interaction between the promoter and the fragment at $-63 \mathrm{~kb}$ was approx. 2-fold higher than that between a fragment located close to the promoter, and approx. 9-fold higher than the background.

\subsection{The $-63 k b p$ and $+48 k b p$ Regions of the PTBP3 Promoter are Open Chromatin Regions}

To verify open chromatin state at the $-63 \mathrm{~kb}$ and $+48 \mathrm{~kb}$ locations of PTBP3 in the PC 3 and PC $3 \mathrm{M}$ cell lines, chromatin immunoprecipitation (ChIP) with antibodies specific for acetylation of histone $\mathrm{H} 3$ on lysine 27 (H3K27Ac) that marked both active promoters and distal enhancers was conducted [30,31] Primer sets for the SYBR green qPCR were designed to amplify the regions of interests $(-63 \mathrm{~kb}$ and $+48 \mathrm{~kb}$ ) upstream and downstream of the РТВP3 promoter region, respectively.

In the PC $3 \mathrm{M}$ cells, the fragment of interest located $48 \mathrm{~kb}$ downstream of the promoter region was significantly (over 60-fold) enriched in H3K27 acetylation. The second analyzed fragment located at $-63 \mathrm{~kb}$ of the PTBP3 locus was also significantly (over 30-fold) enriched in H3K27ac (Figure 3).

In the PC3 cells, an almost 5-fold and a 3-fold enrichment in H3K27Ac at the $-63 \mathrm{~kb}$ and $+48 \mathrm{~kb}$ positions, respectively, was found. The H3K27ac signal levels of fibroblast cell line (VH10) chromatin were not significantly different between the background signal obtained with an Immunoglobulin $\mathrm{G}(\mathrm{IgG})$ antibody across the analyzed regions of interests $(-63 \mathrm{~kb}$ and $+48 \mathrm{~kb})$. In both prostate cancer cell lines, PC3M and PC3, ChIP assays targeting H3K27ac revealed that this type of histone modification was located at the same positions as those identified by the $3 \mathrm{C}$ assay of long-range chromatin interactions with the PTBP3 promoter.

Results obtained in ChIP assay led us to in silico prediction of enhancer elements in the РTBP3 locus. Our 3C approach employed the HindIII restriction enzyme and produced several DNA fragments of $1-16 \mathrm{~kb}$ in size. However, transcriptional enhancers are short DNA fragments (200-1500 bp) [32] that make it necessary to narrow down the likely position of the putative enhancers within the obtained $-63 \mathrm{~kb}$ and $+48 \mathrm{~kb}$ regions in the active PTBP3 gene. To identify any putative enhancer elements localized in these upstream and downstream regions of $P T B P 3$, respectively, we searched the Dragon ENhancers database (DENdb), which predicts enhancers derived from 15 human cell lines form the Encyclopedia of DNA elements (ENCODE) project [33]. DENdb determines enhancers using five different methods (ChromHMM [34], Segway [35], Random-Forest Based Algorithm for Enhancer Identification from Chromatin State RFECS [36], Chromatin signature identification by artificial neural network (CSI-ANN) [37] and ENCODE [38] integrated annotation). 

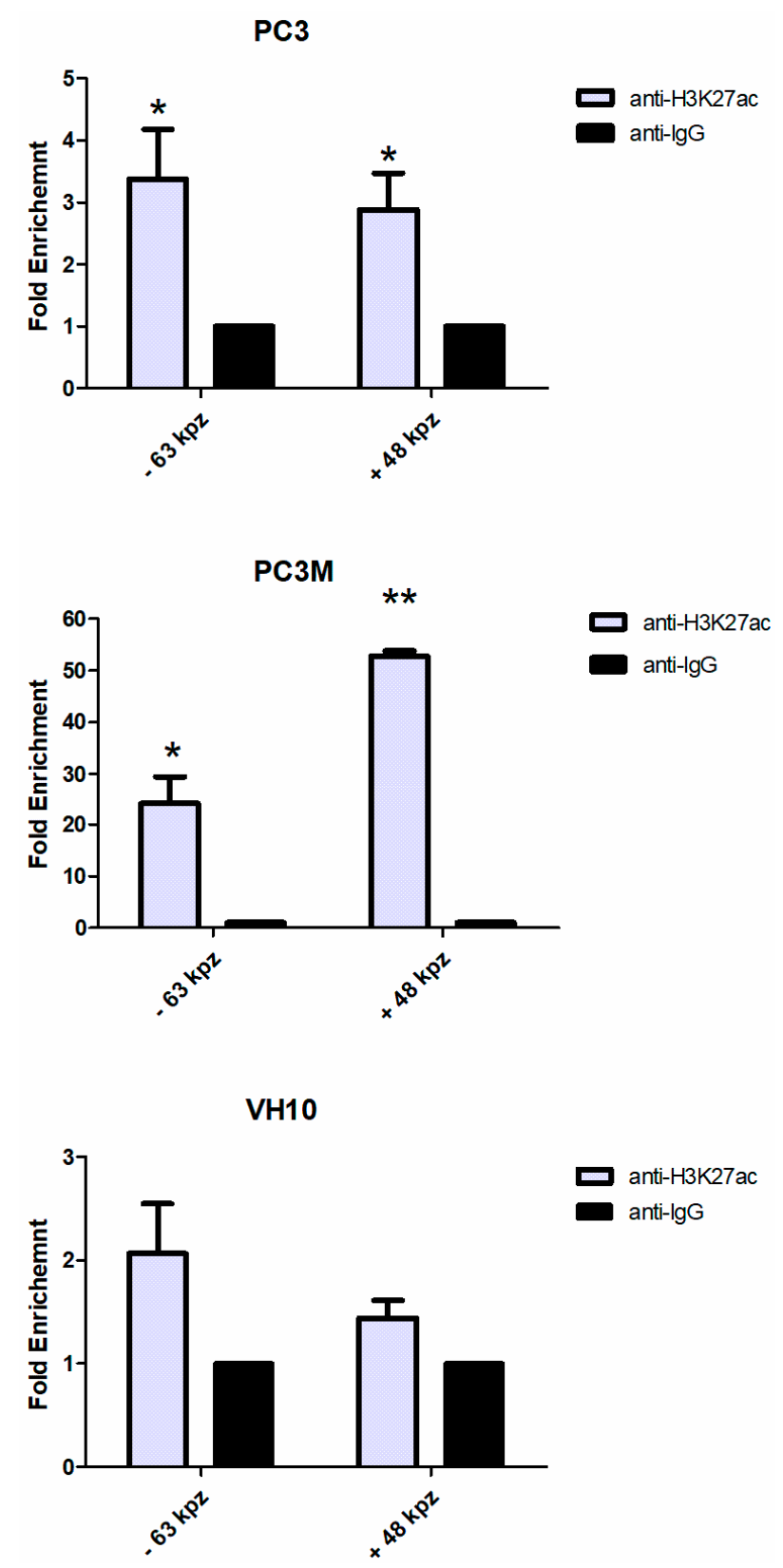

Figure 3. Histone acetylation across the PTBP3 locus region in prostate cancer cells and skin fibroblasts. ChIP was performed using anti-H3K27Ac or a mouse control IgG antibody. H3K27Ac enrichment is shown relative to the IgG. Data are combined from at least two ChIP experiments. All data points were calculated as percentage of input material. Asterisks represent statistically significant changes in H3K27ac enrichment versus anti-IgG, with ${ }^{*} p<0.05$ and ${ }^{* *} p<0.001$.

In DENdb, we searched for putative enhancers focused on chromatin interacting positions of the active PTBP3 gene: $-63 \mathrm{~kb}$ (chr9: 115123248) and $+48 \mathrm{~kb}$ (chr9: 115011604). We narrowed the $-63 \mathrm{~kb}$ region down to two putative regions with enhancers: chr9:115123100-115123500 in lymphoblastoid cell line (Gm12878) and chr9: 115122550-115125100 in cervical cancer cell line (HeLa-S3). In the +48 kb region, we also found two putative enhancer regions in cancerous cell lines: at position chr9: 115010400-115013400 in the Gm12878 lymphoblastoid cell line, and at position chr9: 115010700-115012700 in the HeLa-S3 cervical cancer cell line. 


\section{Discussion}

One of the epigenetic mechanisms of regulation of gene expression are chromatin conformation changes. Three-dimensional (3D) chromatin looping brings widely-separated distant gene regulatory elements into close spatial proximity with gene promoter to facilitate long-range control of gene expression $[8,12,39]$. Chromatin conformation capture (3C) provides information on the 3D chromatin organization of the analyzed loci that typically cover only ten to several hundred $\mathrm{kb}$, using locus-specific primers. In this study, we used $3 C$ to identify long-range chromatin interactions that may be mechanisms of the РТВP3 gene expression regulation. We explored the spatial chromatin architecture of nearly $200 \mathrm{~kb}$ of chromosome 9 encompassing the PTBP3 gene.

Previous results of studies of $P T B P 3$ expression indicated various expression patterns $[20,28,29]$. Our consistent qPCR and ddPCR results indicate a significantly increased level of PTBP3 mRNA in prostate cancer cell lines compared to skin fibroblasts. To confirm that PTBP3 mRNA is overexpressed in prostate cancer cells, we evaluated the PTBP3 expression pattern between prostate cancer and normal tissues samples [on the basis of Gene Expression Omnibus(GEO) and Gene Expression Profiling Interactive Analysis( GEPIA) annotations]. Microarray data obtained from GEO indicate that PTBP3 is upregulated in prostate tumors versus normal prostate tissue (GDS2545/35600; GDS4114/207223). Moreover, upregulation of the РТВP3 gene has been demonstrated in prostate cancer progression states versus benign prostate cancer samples (GDS1439/224618). RNA sequencing expression data from the GEPIA analysis of the PTBP3 expression across normal and cancerous prostate tissue also demonstrate upregulation of the PTBP3 gene in prostate cancer tissue compared to normal samples (Figure S4, Supplementary data). However, the underlying genetic mechanisms responsible for conferring these different $P T B P 3$ expression patterns are still poorly understood.

We evaluated the level of the PTBP3 protein in the freely available Human Protein Atlas database (www.proteinatlas.org). As expected, based on the higher PTBP3 expression in prostate cancer cell lines, a high protein level was detected in many human cancers: lung, stomach, colorectal, urothelial and pancreatic (www.proteinatlas.org). Furthermore, overexpression of the PTBP3 protein in lung and pancreatic cancers was associated with unfavorable prognosis.

However, mechanisms which regulate the PTBP3 expression in cancer cells have never been explored. Therefore, we examined cancerous and non-cancerous cell lines differing in the PTBP3 mRNA levels to identify the spatial chromatin architecture of the PTBP3 locus that can affect the activation of gene expression in PTBP3-expressing cells.

Our study revealed two elements $(-63 \mathrm{~kb}$ and $+48 \mathrm{~kb})$ in a 200-kb region across the locus that looped specifically to the PTBP3 promoter exclusively in PTBP3-expressing prostate cancer cell lines. As expected, no chromatin interactions were identified in the same region in non-cancerous skin fibroblasts with a low level of expression of the РTBP3 gene.

We identified for the first time novel long-range chromatin interactions between the $-63 \mathrm{~kb}$ and $+48 \mathrm{~kb}$ loci and the $P T B P 3$ promotor which activate $P T B P 3$ expression in the cancerous prostate cell lines: PC3 and PC3M. In normal skin fibroblasts, flexible chromatin fibers are observed, with absence of specific long-range looping interactions in the PTBP3 locus. These data suggest that in skin fibroblasts, there is no interaction within the region spanning $200 \mathrm{~kb}$ which could bring distal regulatory elements close to the gene promoter.

Enhancer elements are known to be associated with certain histone modifications-acetylation of lysine 27 in histone H3 (H3K27ac) and methylation of H3K4 [40]. H3K27ac is an important marker for enhancer elements that allows distinguishing between active and inactive enhancer regions according to the expression of proximal genes, in contrast to H3K4me1 that occurs in all enhancers [31]. Moreover, changes in the modifications of active histones, such as histone $\mathrm{H} 3$ acetylation, are also important in the three-dimensional organization of chromatin [41]. Therefore, we evaluated chromatin H3K27 acetylation at looping positions across the PTBP3 gene. Chromatin immunoprecipitation was carried out in the prostate cancer cell lines PC3 and PC3M, and skin fibroblasts VH10 using antibodies specific for acetylated H3K27. 
In the PC3 and PC3M cell lines with a highly active PTBP3 locus, H3K27ac enrichment was detected at the analyzed $-63 \mathrm{~kb}$ and $+48 \mathrm{~kb}$ from the transcription startsites. In skin fibroblasts, in which the PTBP3 locus is inactive, no statistical evidence for acetylated H3K27 was obtained at the analyzed positions.

H3K27 acetylation detected at analyzed regions of the PTBP3 locus in prostate cancer cells (PC3 and PC3M) may suggest that open chromatin regions are located at positions $-63 \mathrm{~kb}$ and $+48 \mathrm{~kb}$ of the PTBP3 promoter, respectively, and may act as epigenetic activation regulators of the PTBP3 gene.

Data from DENdb, compared to our $3 \mathrm{C}$ and ChIP assay results, suggest a potential presence of distal enhancer elements that come into physical contact with proximal promoter via looped out chromatin in the prostate cancer cell lines PC 3 and PC3M. The long-range chromatin looping interactions obtained in our study correlated with the overexpression of the PTBP3 gene in prostate cancer cell lines.

Using the $3 \mathrm{C}$ assay and its derivative methods, it has previously been demonstrated that longrange chromatin interactions regulate many well-known genes associated with prostate cancer through chromatin looping. The abnormal activation of the androgen receptor (AR) is a major example of chromatin looping mechanisms that enhance gene expression in prostate cancer [42]. Recent studies have demonstrated that distal AR binding sites regulate well-known AR target genes, such as PSA Prostate specific antigen), TMPRSS2 (Transmembrane serine protease 2), UGT1A (UDP glucuronosyltransferase family 1 member A complex locus), UBE2C (Ubiquitin conjugating enzyme E2 C), through chromatin looping [43-46]. Moreover, the chromosomal loops of UBE2C have been reported to be a new therapeutic target in castration-resistant prostate cancer [41,46].

Our results are consistent with the present of three-dimensional structural model and open chromatin form of the PTBP3 gene in prostate cancer cell lines (Figure 4). This proposed looping model is clearly correlated with the expression of $P T B P 3$ and suggests that chromatin conformation changes are the main epigenetic mechanism that regulates $P T B P 3$ expression in prostate cancer cells.

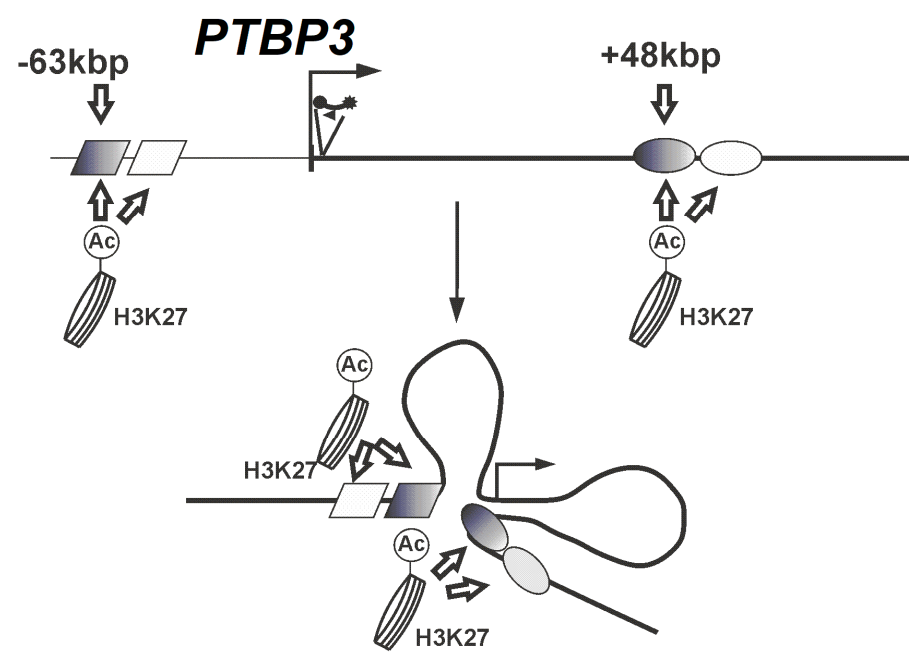

Figure 4. Looping model for PTBP3 gene in prostate cancer cell lines. The bent arrow represents transcriptional start site of the ROD1(PTBP3) gene; the black circle with a star represent 3C Taqman probe (bait). The ellipses and diamonds represent the potential regulatory elements: grey diamond represents the region of chr9: 115123100-115123500 (DENdb); white diamond represents the region of chr9: 115122550-115125100 (DENdb); grey ellipse represents the region of chr9: 115010400-115013400 (DENdb); white ellipse represents the region of chr9:115010700-115012700 (DENdb). 


\section{Materials and Methods}

\subsection{Cell Line Cultures}

The human prostate cancer cell lines PC3 and PC3M were grown in the Roswell Park Memorial Institute (RPMI) 1640 medium supplemented with 10\% fetal bovine serum (FBS), and the human skin fibroblast cell line (VH10) was grown in Dulbecco's Modified Eagle's Medium (DMEM) supplemented with $10 \%$ Fetal Bovine Serum (FBS). The tested cell lines were cultured at $37{ }^{\circ} \mathrm{C}$ in a humidified atmosphere of $5 \% \mathrm{CO}_{2}$. Cells were passaged every 2-3 days for exponential growth.

\subsection{RNA Isolation and $c D N A$ Synthesis}

The total RNA from human prostate cancer cell lines (PC3, PC3M) and fibroblasts (VH10) was isolated using the High Pure RNA Isolation Kit (Roche, Mannheim, Germany) according to the manufacturer's protocol. Complementary DNA (cDNA) was generated used the Transcriptor High Fidelity cDNA Synthesis Kit (Roche, Mannheim, Germany) with Anchored-oligo(dT)18 Primer. Denaturation of the template-primer mixture was carried out by heating the tube for $10 \mathrm{~min}$ at $65^{\circ} \mathrm{C}$. Reverse transcription was carried out at $50{ }^{\circ} \mathrm{C}$ for $30 \mathrm{~min}$ and at $85^{\circ} \mathrm{C}$ for $5 \mathrm{~min}$. The purity of cDNA was tested with agarose gel electrophoresis.

\subsection{Real-time Reverse Transcriptase Polymerase Chain Reaction (RT-PCR)}

Quantitative reverse transcriptase real-time PCR (qRT-PCR) was performed using RealTime Ready Custom Panels 96-8 (Roche, Mannheim, Germany) with primers and probe from Universal ProbeLibrary (Roche, Mannheim, Germany) specific to the PTBP3, GAPDH and PBGD genes, and run with LC480 Probes Master (Roche, Mannheim, Germany). The experiment was performed in triplicates for each cell line. Real-time PCR cycling conditions were as follows: One cycle at $95{ }^{\circ} \mathrm{C}$, $10 \mathrm{~min} ; 45$ cycles of denaturation $\left(95^{\circ} \mathrm{C}, 10 \mathrm{~s}\right)$, annealing $\left(60^{\circ} \mathrm{C}, 30 \mathrm{~s}\right)$ extension $\left(72{ }^{\circ} \mathrm{C}, 1 \mathrm{~s}\right)$ and cooling $\left(4^{\circ} \mathrm{C}, \infty\right)$.

\subsection{Digital Droplet Polymerase Chain Reaction (ddPCR)}

Digital droplet PCR was conducted to quantify the concentration of the $R$ transcripts in prostate cancer cells and skin fibroblasts. TaqMan Gene Expression Assay was used to confirm the PTBP3 gene expression profile by another quantifying method: ddPCR using the QX100 system (Bio-Rad, Hercules, CA, USA). The copy numbers for each target were averaged across duplicates and normalized to PBGD references genes. Endogenous mRNA levels were measured by ddPCR using the QuantaLife droplet digital PCR system (Bio-Rad, Hercules, CA, USA) according to the manufacturer's instructions. Briefly, the $20-\mu \mathrm{L}$ ddPCR mixture was prepared by combining cDNA, primers and probes with ddPCR Supermix (Bio-Rad, Hercules, CA, USA). Oil emulsion droplets for each sample were prepared using the QuantaLife droplet generator (Bio-Rad, Hercules, CA, USA). PCR reaction was under the following conditions: One cycle at $95^{\circ} \mathrm{C}$ for $10 \mathrm{~min}, 45$ cycles of $95^{\circ} \mathrm{C}$ for $30 \mathrm{~s}, 60^{\circ} \mathrm{C}$ for $1 \mathrm{~min}$, and $98^{\circ} \mathrm{C}$ for $10 \mathrm{~min}$ in a standard thermal cycler (Bio-Rad, Hercules, CA, USA). Plates were read on a QuantaLife droplet reader (Bio-Rad, Hercules, CA, USA), and the concentrations (copy numbers) of the targets in the samples were determined using the QuantaSoft software (QuantaSoft Analysis Pro software version 1.0).

\subsection{Gene Expression Databases}

The datasets for the analysis and visualization of the PBP3 expression level in prostate tumor versus normal prostate samples were obtained from several gene expression repositories: Gene Expression Ominbus (GEO) [47], the Cancer Genome Atlas (TCGA) [48] and Genotype-Tissue Expression (GTEx) [49]. Additionally, the Gene Expression Profiling Interactive Analysis (GEPIA) web-based tool was used for comprehensive expression analyses based on TCGA and GTEx data [50]. 


\subsection{Chromosome Conformation Capture (3C)}

$3 \mathrm{C}$ experiments were completed as described previously [51] with minor modifications. Briefly, up to 10 million exponentially growing cells were fixed with $1 \%$ formaldehyde for $10 \mathrm{~min}$ at room temperature. The cells were lysed in $5 \mathrm{~mL}$ of cold lysis buffer $(10 \mathrm{mM}$ Tris $\mathrm{pH} 8,10 \mathrm{mM} \mathrm{NaCl}, 0.2 \%$ NP-40) including $1 \times$ protease inhibitor, and nuclei were collected by centrifugation. The resulting cell nuclei were pelleted in $0.5 \mathrm{~mL}$ of the appropriate $1.2 \times$ restriction buffer, and sodium dodecyl sulfate (SDS) was added to each tube to a final concentration of $0.3 \%$. Following extraction with $1.8 \%$ Triton X-100, chromatin was digested overnight at $37^{\circ} \mathrm{C}$ with $2000 \mathrm{U}$ of HindIII (Roche, Mannheim, Germany). Ligations were performed in a total reaction volume of $6.5 \mathrm{~mL}$ of ligation buffer, using $100 \mathrm{U}$ of T4 DNA ligase and incubation at $14{ }^{\circ} \mathrm{C}$ for $4 \mathrm{~h}$, followed by further incubation at room temperature for $30 \mathrm{~min}$. DNA was extracted with phenol-chloroform followed by ethanol precipitation. The efficacy of restriction enzyme digestion was examined using SYBR green qPCR analysis with specific primer sets (Supplementary data Table S3) and was found to be more than $85 \%$ for each 3C library. The concentrations of $3 \mathrm{C}$ libraries were determined by quantitative PCR using the concINT9R2 $\mathrm{F} / \mathrm{R}$ primer set and compared to a genomic DNA reference of known concentration. Samples were subsequently diluted to a concentration of $100 \mathrm{ng} / \mathrm{mL}$. The Taqman qPCR technique was used to quantify the ligation frequency of the РTBP3 gene. The Taqman probe (bait) and the reverse primer were generated within a restriction fragment at the promoter, and multiple forward primers were designed within restriction sites in distal regions across the PTBP3 locus spanning a genomic distance of 203,723 kb (Supplementary data Table S1). The visual representation of DNase-seq and ChIP-seq (ENCODE Project, 2012) freely available at Genome Browser (University of California, Santa Cruz, CA, USA; http:/ /genome.ucsc.edu/encode/) was used to evaluate DNase I-hypersensitive sites in the PTBP3 locus and the flanking region upstream and downstream. Multiple forward primers at $-79.7 \mathrm{~kb}$, $-63.2 \mathrm{~kb},-30.7 \mathrm{~kb},-6.8 \mathrm{~kb},+48.4 \mathrm{~kb},+71.3 \mathrm{~kb}$ and $+119.3 \mathrm{~kb}$ in reference to the PTBP3 transcriptional start site were designed. To analyze ligation products across the $3 \mathrm{C}$ templates, $200 \mathrm{ng}$ of a $3 \mathrm{C}$ template was used per $20 \mu \mathrm{L}$ of Taqman qPCR reaction. To account for differences in independently prepared $3 \mathrm{C}$ samples, the qPCR data for each sample were normalized to the results obtained for primers designed for the housekeeping gene ERCC3 (ERCC Excision Repair 3), located in an area with the same chromatin structure in all types of cells. Each qPCR reaction was performed in triplicate, and the data presented were the average of two to four independent experimental results for all PCR reactions.

\subsection{Chromatin Immunoprecipitation (ChIP)}

ChIP assays were performed using Magna ChIPTM G (Millipore, Burlington, MA, USA) protocol with minor modifications. Approximately $4-5 \times 10^{6}$ cells (on a $100 \mathrm{~mm}$ culture dish) were cross-linked with $1 \%$ formaldehyde for $10 \mathrm{~min}$ at room temperature. The reaction was stopped with glycine at $0.125 \mathrm{M}$. The cells were washed with cold Phosphate buffered saline (PBS), scraped and collected by centrifugation. Nuclei preparation and chromatin digestion was carried out using SimpleChIP®Cell Lysis Buffers A \& B and MNase from Cell Signaling Technology (2316 WZ Leiden, The Netherlands). Chromatin was digested with 1000 units of MNase at $37^{\circ} \mathrm{C}$ for $30 \mathrm{~min}$, followed by sonication to an average size of $150 \mathrm{bp}$ to $500 \mathrm{bp}$. Chromatin equivalents of $\sim 1 \times 10^{6}$ cells were suspended in Dilution Buffer with $1 \times$ protease inhibitor cocktail (Millipore, Burlington, MA, USA) and precleared by incubation with $5 \mu \mathrm{L}$ of protein $\mathrm{G}$ magnetic beads for $1 \mathrm{~h}$ at $4{ }^{\circ} \mathrm{C}$. An aliquot of chromatin was removed and saved as "Input". The reminder of supernatant containing precleared chromatin was immunoprecipitated using antibodies: $2 \mu \mathrm{L}$ of H3K27Ac or $1 \mu \mathrm{L}$ of normal mouse IgG (17-683, Millipore, Burlington, MA, USA), $20 \mu \mathrm{L}$ of protein $\mathrm{G}$ magnetic beads blocked with bovine serum albumin (BSA) (washed $2 \times$ with $100 \mu \mathrm{L}$ of BSA $0.5 \%, 400 \mu \mathrm{L}$ of Dilution Buffer, $20 \mu \mathrm{L}$ of $25 \times$ protease inhibitor cocktail (PIC) and $50 \mu \mathrm{L}$ of BSA $0.5 \%$. Immunoprecipitations were performed overnight at $4{ }^{\circ} \mathrm{C}$. Protein G bead-antibody/chromatin complexes were washed as described in the Magna ChIPTM G (Millipore, Burlington, MA, USA) protocol. Protein/DNA complexes were eluted, and cross-links were reversed by incubation with proteinase $\mathrm{K}(10 \mu \mathrm{g} / \mathrm{mL})$ and Elution Buffer (Millipore, 
Burlington, MA, USA) for $2 \mathrm{~h}$ at $62{ }^{\circ} \mathrm{C}$ and $10 \mathrm{~min}$ at $95^{\circ} \mathrm{C}$. DNA was purified using spin columns as described in the Magna ChIPTM G (Millipore, Burlington, MA, USA) protocol. Enrichment was analyzed using SYBR Green qPCR. qPCR primers (Supplementary data Table S2) were located at the selected positions: $-63 \mathrm{~kb}$ and $+48 \mathrm{~kb}$ in the PTBP3 gene.

\section{Conclusions}

Our study revealed two elements ( $-63 \mathrm{~kb}$ and $+48 \mathrm{~kb}$ ) in a 200-kb region across the locus that looped specifically to the PTBP3 promoter exclusively in PTBP3-expressing prostate cancer cell lines. The model of three dimensional chromatin conformation in the PTBP3 locus obtained for prostate cancer cell lines with high PTBP3 expression suggests, that the variable chromatin conformation is a mechanism that regulates its expression.

Supplementary Materials: Supplementary Materials can be found at http:/ / www.mdpi.com/1422-0067/20/2/ 242/s1.

Author Contributions: Conceptualization, M.A.L. and S.H.; methodology M.K., A.J., K.K., M.A.L.; S.H., software, M.K.; validation, M.K.; formal analysis, M.K., M.A.L.; investigation, M.K., M.A.L.; resources, M.K., M.A.L.; data curation, M.K., M.A.L.; writing—original draft preparation, M.K., M.A.L.; writing—review and editing, M.A.L., S.H., J.K.; visualization, M.K.; supervision, M.A.L.; project administration M.A.L., J.K.; funding acquisition, M.A.L., J.K.

Funding: This research was funded by Foundation for Polish Science, co-financed by the European Union, Regional Development Fund (HOMING PLUS/2010-2/7).

Conflicts of Interest: The authors declare no conflict of interest.

\section{References}

1. Narlikar, G.J.; Fan, H.-Y.; Kingston, R.E. Cooperation between complexes that regulate chromatin structure and transcription. Cell 2002, 108, 475-487. [CrossRef]

2. Bevilacqua, A.; Ceriani, M.C.; Capaccioli, S.; Nicolin, A. Post-transcriptional regulation of gene expression by degradation of messenger RNAs. J. Cell. Physiol. 2003, 195, 356-372. [CrossRef] [PubMed]

3. Stoneley, M.; Willis, A.E. Cellular internal ribosome entry segments: Structures, trans-acting factors and regulation of gene expression. Oncogene 2004, 23, 3200-3207. [CrossRef] [PubMed]

4. Jaenisch, R.; Bird, A. Epigenetic regulation of gene expression: How the genome integrates intrinsic and environmental signals. Nat. Genet. 2003, 33, 245-254. [CrossRef] [PubMed]

5. Singh, P.K.; Campbell, M.J. The Interactions of microRNA and Epigenetic Modifications in Prostate Cancer. Cancers 2013, 5, 998-1019. [CrossRef] [PubMed]

6. Ballestar, E.; Esteller, M. The impact of chromatin in human cancer: Linking DNA methylation to gene silencing. Carcinogenesis 2002, 23, 1103-1109. [CrossRef] [PubMed]

7. Kouzarides, T. Chromatin modifications and their function. Cell 2007, 128, 693-705. [CrossRef]

8. Dekker, J. Gene regulation in the third dimension. Science 2008, 319, 1793-1794. [CrossRef]

9. Simonis, M.; Klous, P.; Splinter, E.; Moshkin, Y.; Willemsen, R.; de Wit, E.; van Steensel, B.; de Laat, W. Nuclear organization of active and inactive chromatin domains uncovered by chromosome conformation capture-on-chip (4C). Nat. Genet. 2006, 38, 1348-1354. [CrossRef]

10. Zhao, Z.; Tavoosidana, G.; Sjölinder, M.; Göndör, A.; Mariano, P.; Wang, S.; Kanduri, C.; Lezcano, M.; Sandhu, K.S.; Singh, U.; et al. Circular chromosome conformation capture (4C) uncovers extensive networks of epigenetically regulated intra- and interchromosomal interactions. Nat. Genet. 2006, 38, 1341-1347. [CrossRef]

11. Dostie, J.; Richmond, T.A.; Arnaout, R.A.; Selzer, R.R.; Lee, W.L.; Honan, T.A.; Rubio, E.D.; Krumm, A.; Lamb, J.; Nusbaum, C.; et al. Chromosome Conformation Capture Carbon Copy (5C): A massively parallel solution for mapping interactions between genomic elements. Genome Res. 2006, 16, 1299-1309. [CrossRef] [PubMed]

12. Lieberman-Aiden, E.; van Berkum, N.L.; Williams, L.; Imakaev, M.; Ragoczy, T.; Telling, A.; Amit, I.; Lajoie, B.R.; Sabo, P.J.; Dorschner, M.O.; et al. Comprehensive mapping of long-range interactions reveals folding principles of the human genome. Science 2009, 326, 289-293. [CrossRef] [PubMed] 
13. Kolovos, P.; van de Werken, H.J.; Kepper, N.; Zuin, J.; Brouwer, R.W.; Kockx, C.E.; Wendt, K.S.; van IJcken, W.F.; Grosveld, F.; Knoch, T.A. Targeted Chromatin Capture (T2C): A novel high resolution high throughput method to detect genomic interactions and regulatory elements. Epigenet. Chromatin 2014, 7, 10. [CrossRef] [PubMed]

14. Hughes, J.R.; Roberts, N.; McGowan, S.; Hay, D.; Giannoulatou, E.; Lynch, M.; De Gobbi, M.; Taylor, S.; Gibbons, R.; Higgs, D.R. Analysis of hundreds of cis-regulatory landscapes at high resolution in a single, high-throughput experiment. Nat. Genet. 2014, 46, 205-212. [CrossRef] [PubMed]

15. Kubiak, M.; Lewandowska, M.A. Can chromatin conformation technologies bring light into human molecular pathology? Acta Biochim. Pol. 2015, 62, 483-489. [CrossRef] [PubMed]

16. Spellman, R.; Rideau, A.; Matlin, A.; Gooding, C.; Robinson, F.; McGlincy, N.; Grellscheid, S.N.; Southby, J.; Wollerton, M.; Smith, C.W.J. Regulation of alternative splicing by PTB and associated factors. Biochem. Soc. Trans. 2005, 33, 457-460. [CrossRef] [PubMed]

17. Sawicka, K.; Bushell, M.; Spriggs, K.A.; Willis, A.E. Polypyrimidine-tract-binding protein: A multifunctional RNA-binding protein. Biochem. Soc. Trans. 2008, 36, 641-647. [CrossRef] [PubMed]

18. Wollerton, M.C.; Gooding, C.; Wagner, E.J.; Garcia-Blanco, M.A.; Smith, C.W.J. Autoregulation of polypyrimidine tract binding protein by alternative splicing leading to nonsense-mediated decay. Mol. Cell 2004, 13, 91-100. [CrossRef]

19. Suckale, J.; Wendling, O.; Masjkur, J.; Jäger, M.; Münster, C.; Anastassiadis, K.; Stewart, A.F.; Solimena, M. PTBP1 Is Required for Embryonic Development before Gastrulation. PLoS ONE 2011, 6, e16992. [CrossRef] [PubMed]

20. Yamamoto, H.; Tsukahara, K.; Kanaoka, Y.; Jinno, S.; Okayama, H. Isolation of a mammalian homologue of a fission yeast differentiation regulator. Mol. Cell. Biol. 1999, 19, 3829-3841. [CrossRef]

21. Brazão, T.F.; Demmers, J.; van IJcken, W.; Strouboulis, J.; Fornerod, M.; Romão, L.; Grosveld, F.G. A new function of ROD1 in nonsense-mediated mRNA decay. FEBS Lett. 2012, 586, 1101-1110. [CrossRef] [PubMed]

22. Spellman, R.; Llorian, M.; Smith, C.W.J. Crossregulation and functional redundancy between the splicing regulator PTB and its paralogs $\mathrm{nPTB}$ and ROD1. Mol. Cell 2007, 27, 420-434. [CrossRef] [PubMed]

23. Ott, C.J.; Blackledge, N.P.; Leir, S.-H.; Harris, A. Novel regulatory mechanisms for the CFTR gene. Biochem. Soc. Trans. 2009, 37, 843-848. [CrossRef] [PubMed]

24. Zhang, Z.; Ott, C.J.; Lewandowska, M.A.; Leir, S.-H.; Harris, A. Molecular mechanisms controlling CFTR gene expression in the airway. J. Cell. Mol. Med. 2012, 16, 1321-1330. [CrossRef] [PubMed]

25. Gheldof, N.; Smith, E.M.; Tabuchi, T.M.; Koch, C.M.; Dunham, I.; Stamatoyannopoulos, J.A.; Dekker, J. Cell-type-specific long-range looping interactions identify distant regulatory elements of the CFTR gene. Nucleic Acids Res. 2010, 38, 4325-4336. [CrossRef] [PubMed]

26. Wang, S.; Wen, F.; Wiley, G.B.; Kinter, M.T.; Gaffney, P.M. An enhancer element harboring variants associated with systemic lupus erythematosus engages the TNFAIP3 promoter to influence A20 expression. PLoS Genet. 2013, 9, e1003750. [CrossRef] [PubMed]

27. LeBlanc, S.E.; Wu, Q.; Barutcu, A.R.; Xiao, H.; Ohkawa, Y.; Imbalzano, A.N. The PPAR $\gamma$ locus makes long-range chromatin interactions with selected tissue-specific gene loci during adipocyte differentiation in a protein kinase A dependent manner. PLoS ONE 2014, 9, e86140. [CrossRef] [PubMed]

28. Ooi, A.T.; Gower, A.C.; Zhang, K.X.; Vick, J.L.; Hong, L.; Nagao, B.; Wallace, W.D.; Elashoff, D.A.; Walser, T.C.; Dubinett, S.M.; et al. Molecular profiling of premalignant lesions in lung squamous cell carcinomas identifies mechanisms involved in stepwise carcinogenesis. Cancer Prev. Res. 2014, 7, 487-495. [CrossRef]

29. Liang, X.; Shi, H.; Yang, L.; Qiu, C.; Lin, S.; Qi, Y.; Li, J.; Zhao, A.; Liu, J. Inhibition of polypyrimidine tract-binding protein 3 induces apoptosis and cell cycle arrest, and enhances the cytotoxicity of 5- fluorouracil in gastric cancer cells. Br. J. Cancer 2017, 116, 903-911. [CrossRef]

30. Ernst, J.; Kheradpour, P.; Mikkelsen, T.S.; Shoresh, N.; Ward, L.D.; Epstein, C.B.; Zhang, X.; Wang, L.; Issner, R.; Coyne, M.; et al. Mapping and analysis of chromatin state dynamics in nine human cell types. Nature 2011, 473, 43-49. [CrossRef]

31. Creyghton, M.P.; Cheng, A.W.; Welstead, G.G.; Kooistra, T.; Carey, B.W.; Steine, E.J.; Hanna, J.; Lodato, M.A.; Frampton, G.M.; Sharp, P.A.; et al. Histone H3K27ac separates active from poised enhancers and predicts developmental state. Proc. Natl. Acad. Sci. USA 2010, 107, 21931-21936. [CrossRef] [PubMed]

32. Schaffner, W. Enhancers, enhancers-From their discovery to today's universe of transcription enhancers. Biol. Chem. 2015, 396, 311-327. [CrossRef] [PubMed] 
33. Ashoor, H.; Kleftogiannis, D.; Radovanovic, A.; Bajic, V.B. DENdb: Database of integrated human enhancers. Database 2015, 2015. [CrossRef] [PubMed]

34. Ernst, J.; Kellis, M. ChromHMM: Automating chromatin-state discovery and characterization. Nat. Methods 2012, 9, 215-216. [CrossRef] [PubMed]

35. Hoffman, M.M.; Buske, O.J.; Wang, J.; Weng, Z.; Bilmes, J.A.; Noble, W.S. Unsupervised pattern discovery in human chromatin structure through genomic segmentation. Nat. Methods 2012, 9, 473-476. [CrossRef] [PubMed]

36. Rajagopal, N.; Xie, W.; Li, Y.; Wagner, U.; Wang, W.; Stamatoyannopoulos, J.; Ernst, J.; Kellis, M.; Ren, B. RFECS: A random-forest based algorithm for enhancer identification from chromatin state. PLoS Comput. Biol. 2013, 9, e1002968. [CrossRef]

37. Firpi, H.A.; Ucar, D.; Tan, K. Discover regulatory DNA elements using chromatin signatures and artificial neural network. Bioinformatics 2010, 26, 1579-1586. [CrossRef]

38. Landt, S.G.; Marinov, G.K.; Kundaje, A.; Kheradpour, P.; Pauli, F.; Batzoglou, S.; Bernstein, B.E.; Bickel, P.; Brown, J.B.; Cayting, P.; et al. ChIP-seq guidelines and practices of the ENCODE and modENCODE consortia. Genome Res. 2012, 22, 1813-1831. [CrossRef]

39. Miele, A.; Dekker, J. Mapping cis- and trans-chromatin interaction networks using chromosome conformation capture (3C). Methods Mol. Biol. 2009, 464, 105-121.

40. Heintzman, N.D.; Stuart, R.K.; Hon, G.; Fu, Y.; Ching, C.W.; Hawkins, R.D.; Barrera, L.O.; Van Calcar, S.; $\mathrm{Qu}, \mathrm{C}$.; Ching, K.A.; et al. Distinct and predictive chromatin signatures of transcriptional promoters and enhancers in the human genome. Nat. Genet. 2007, 39, 311-318. [CrossRef]

41. Jia, R.; Chai, P.; Zhang, H.; Fan, X. Novel insights into chromosomal conformations in cancer. Mol. Cancer 2017, 16, 173. [CrossRef] [PubMed]

42. Wu, D.; Zhang, C.; Shen, Y.; Nephew, K.P.; Wang, Q. Androgen receptor-driven chromatin looping in prostate cancer. Trends Endocrinol. Metab. 2011, 22, 474-480. [CrossRef] [PubMed]

43. Wang, Q.; Carroll, J.S.; Brown, M. Spatial and temporal recruitment of androgen receptor and its coactivators involves chromosomal looping and polymerase tracking. Mol. Cell 2005, 19, 631-642. [CrossRef] [PubMed]

44. Takayama, K.; Kaneshiro, K.; Tsutsumi, S.; Horie-Inoue, K.; Ikeda, K.; Urano, T.; Ijichi, N.; Ouchi, Y.; Shirahige, K.; Aburatani, H.; et al. Identification of novel androgen response genes in prostate cancer cells by coupling chromatin immunoprecipitation and genomic microarray analysis. Oncogene 2007, 26, 4453-4463. [CrossRef] [PubMed]

45. Wang, Q.; Li, W.; Liu, X.S.; Carroll, J.S.; Jänne, O.A.; Keeton, E.K.; Chinnaiyan, A.M.; Pienta, K.J.; Brown, M. A hierarchical network of transcription factors governs androgen receptor-dependent prostate cancer growth. Mol. Cell 2007, 27, 380-392. [CrossRef] [PubMed]

46. Chen, Z.; Zhang, C.; Wu, D.; Chen, H.; Rorick, A.; Zhang, X.; Wang, Q. Phospho-MED1-enhanced UBE2C locus looping drives castration-resistant prostate cancer growth. EMBO J. 2011, 30, 2405-2419. [CrossRef] [PubMed]

47. Home-GEO-NCBI. Available online: https://www.ncbi.nlm.nih.gov/geo/ (accessed on 23 July 2018).

48. Cancer Genome Atlas Research Network; Weinstein, J.N.; Collisson, E.A.; Mills, G.B.; Shaw, K.R.M.; Ozenberger, B.A.; Ellrott, K.; Shmulevich, I.; Sander, C.; Stuart, J.M. The Cancer Genome Atlas Pan-Cancer analysis project. Nat. Genet. 2013, 45, 1113-1120. [CrossRef] [PubMed]

49. GTEx Consortium Human genomics. The Genotype-Tissue Expression (GTEx) pilot analysis: Multitissue gene regulation in humans. Science 2015, 348, 648-660. [CrossRef]

50. Tang, Z.; Li, C.; Kang, B.; Gao, G.; Li, C.; Zhang, Z. GEPIA: A web server for cancer and normal gene expression profiling and interactive analyses. Nucleic Acids Res. 2017, 45, W98-W102. [CrossRef]

51. Hagège, H.; Klous, P.; Braem, C.; Splinter, E.; Dekker, J.; Cathala, G.; de Laat, W.; Forné, T. Quantitative analysis of chromosome conformation capture assays (3C-qPCR). Nat. Protoc. 2007, 2, 1722-1733. [CrossRef]

(C) 2019 by the authors. Licensee MDPI, Basel, Switzerland. This article is an open access article distributed under the terms and conditions of the Creative Commons Attribution (CC BY) license (http:/ / creativecommons.org/licenses/by/4.0/). 